\title{
When dermoscopy supports the final diagnosis. A phlegmon and abscess of the neck as a complication of pediculosis capitis
}

\section{Dermoskopia jako metoda potwierdzająca ostateczne rozpoznanie. Pacjentka z ropowicą i ropniem szyi jako powikłaniami wszawicy głowowej}

\author{
Anna Płaszczyńska', Martyna Sławińska', Tomasz K. Nowicki², Grzegorz Śmigielski , Roman J. Nowicki', \\ Michał Sobjanek'
}

\author{
'Department of Dermatology, Venereology and Allergology, Medical University of Gdansk, Poland \\ ${ }^{2} 2^{\text {nd }}$ Department of Radiology, Medical University of Gdansk, Poland \\ ${ }^{3}$ Department of Otolaryngology, Medical University of Gdansk, Poland \\ 'Katedra i Klinika Dermatologii, Wenerologii i Alergologii, Gdański Uniwersytet Medyczny, Polska \\ 2Zakład Radiologii, Gdański Uniwersytet Medyczny, Polska \\ ${ }^{3}$ Klinika Otolaryngologii, Gdański Uniwersytet Medyczny, Polska
}

\section{CORRESPONDING AUTHOR/} AUTOR DO KORESPONDENCJI:

dr n. med. Martyna Sławińska Katedra i Klinika Dermatologii, Wenerologii i Alergologii Gdański Uniwersytet Medyczny Gdańsk, Polska tel.: +48585844014 e-mail: mslawinska@gumed.edu.pl

\begin{abstract}
Introduction: Pediculosis capitis is a common parasitic disease that occurs most frequently in childhood. The main symptom is pruritus of the scalp. Serious, life-threating complications have been rarely reported in literature. Objective: To present severe complications of neglected pediculosis capitis and utility of dermoscopy in making a final diagnosis.
\end{abstract}

Case report: A 38-year-old woman presented to emergency department with the presence of painful, unilateral neck tumor and fever as well as multiple, painful ulcers within the scalp and neck. Based on clinical and computed tomography assessment phlegmon and abscess of the neck were diagnosed. After dermatological assessment, based on clinical and dermoscopic assessment, active pediculosis capitis with secondary bacterial infection was recognized - the most probable initial cause of the life-threating bacterial complications.

Conclusions: Pediculosis capitis is generally associated with a very good prognosis, however when accompanied with particular comorbidities or neglect it can lead to serious complications.

\section{STRESZCZENIE}

Wprowadzenie: Wszawica głowowa jest powszechną chorobą pasożytniczą, która najczęściej dotyczy dzieci. Główny jej objaw to świąd skóry owłosionej głowy. W piśmiennictwie rzadko opisywane są poważne, zagrażające życiu powikłania wszawicy głowowej.

Cel pracy: Przedstawienie przypadku poważnych powikłań zaniedbanej wszawicy głowowej oraz przydatności dermoskopii w postawieniu ostatecznej diagnozy.

Opis przypadku: Kobieta 38-letnia zgłosiła się na oddział ratunkowy z powodu bolesnego, jednostronnego guza szyi, gorączki oraz licznych, bolesnych owrzodzeń skóry głowy i szyi. Na podstawie obrazu klinicznego i wyniku tomografii komputerowej zdiagnozowano ropowicę oraz ropień szyi. Po konsultacji dermatologicznej, na podstawie oceny klinicznej i dermoskopowej rozpoznano wszawicę skóry owłosionej gło- 
wy z wtórną infekcją bakteryjną, która była najbardziej prawdopodobną pierwotną przyczyną zagrażających życiu powikłań bakteryjnych.

Wnioski: Wszawica skóry owłosionej głowy w większości przypadków wiąże się z bardzo dobrym rokowaniem, jednak w połączeniu z określonymi chorobami współistniejącymi lub zaniedbaniem higienicznym może prowadzić do poważnych powikłań.

Key words: dermoscopy, pediculosis capitis, complications, abscess, phlegmon.

Słowa kluczowe: dermoskopia, wszawica skóry owłosionej głowy, powikłania, ropień, ropowica.

\section{INTRODUCTION}

Pediculosis capitis is a common parasitic disease that occurs most frequently in childhood, with peak incidence between 6-12 years of age [1]. The main symptom of the presence of head lice is pruritus of scalp areas, caused by lice bites, but it may also be asymptomatic [1]. Possible complications of pediculosis capitis include excoriations, eczematous dermatitis, impetigo, alopecia, lymphadenopathy and bacterial cellulitis [1-4]. Serious, life-threating complications of pediculosis capitis have been rarely reported in the literature.

\section{OBJECTIVE}

To present severe complications of neglected pediculosis capitis and utility of dermoscopy in making a final diagnosis.

\section{CASE REPORT}

A 38-year-old woman, with an alcohol addiction and untreated epilepsy, presented to an emergency department due to painful, uniliteral neck tumor, bilateral cervical lymphadenopathy, fever, and multiple, painful ulcers within the scalp and neck (figs. 1 A, B). Based on clinical picture and computed tomography findings phlegmon and abscess of the neck were diagnosed (fig. 2).

The abscess was incised and drained and purulent content was taken for microbiological examination. Empirical antibiotic therapy, including $600 \mathrm{mg}$ of clindamycin (3 times per day, intravenously) and $1 \mathrm{~g}$ of ceftriaxone (2 times per day, intravenously), was administered. Subsequently, the woman was consulted at dermatology department. Clinical presentation was equivocal, but trichoscopic assessment showed vital nits, what confirmed the diagnosis of

\section{WPROWADZENIE}

Wszawica skóry owłosionej głowy jest powszechną chorobą pasożytniczą, która występuje najczęściej w dzieciństwie, a szczyt zachorowań przypada na 6.-12. roku życia [1]. Głównym objawem obecności wszy głowowych jest świąd skóry głowy spowodowany ukąszeniami. Choroba może także przebiegać bezobjawowo [1]. Możliwe powikłania wszawicy głowowej to: przeczosy, wypryskowe zapalenie skóry, liszajec, łysienie, powiększenie węzłów chłonnych i bakteryjne zapalenie tkanki łącznej [1-4]. W piśmiennictwie rzadko opisywano poważne, zagrażające życiu powikłania wszawicy głowowej.

\section{CEL PRACY}

Przedstawienie poważnych powikłań zaniedbanej wszawicy głowowej oraz przedstawienie przydatności dermoskopii w ustaleniu ostatecznego rozpoznania.

\section{OPIS PRZYPADKU}

Kobieta 38-letnia, uzależniona od alkoholu, z nieleczoną padaczką, zgłosiła się na oddział ratunkowy z powodu bolesnego guza szyi, obustronnego powiększenia szyjnych węzłów chłonnych, gorączki oraz licznych, bolesnych owrzodzeń skóry głowy i szyi (ryc. 1 A, B). Na podstawie obrazu klinicznego i wyników tomografii komputerowej rozpoznano ropowicę i ropień szyi (ryc. 2).

Ropień nacięto i zdrenowano oraz pobrano treść ropną do badania mikrobiologicznego. Zastosowano empiryczną antybiotykoterapię: $600 \mathrm{mg}$ klindamycyny (3 razy dziennie dożylnie) i 1 g ceftriaksonu (2 razy dziennie dożylnie). Następnie pacjentka została skonsultowana w Klinice. Obraz kliniczny był niejednoznaczny, ale ocena trichoskopowa wykazała obecność żywych gnid, co potwierdziło rozpoznanie wszawicy głowowej 

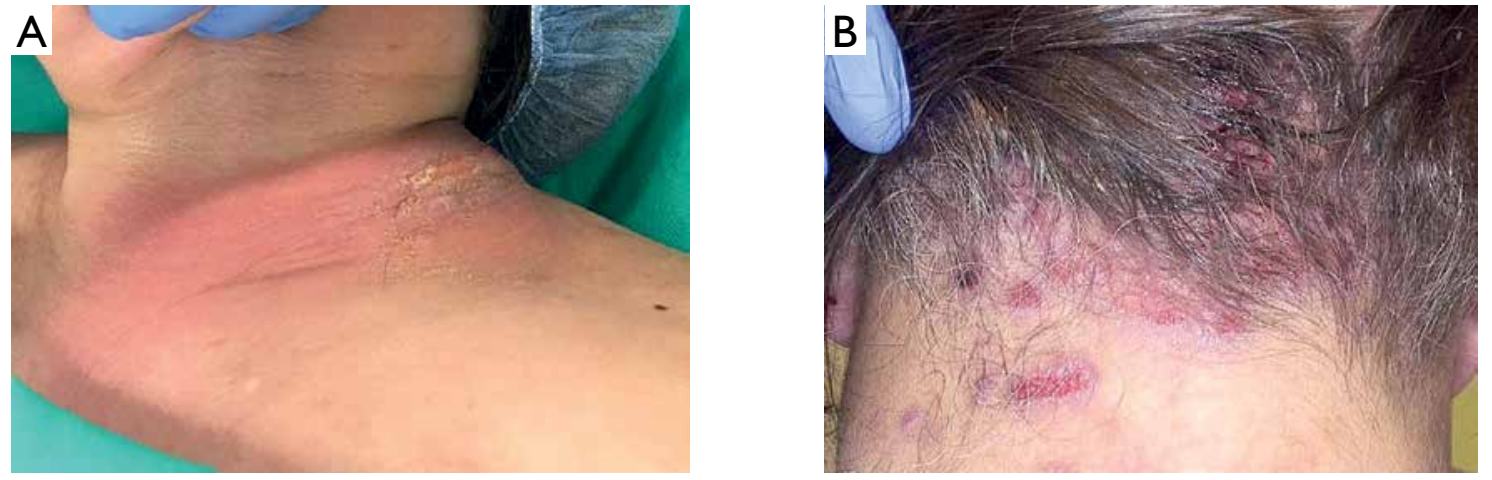

Figure I. A - Unilateral neck tumour. B - Multiple ulcers within the scalp and neck

Rycina I. A - Jednostronny guz szyi. B - Mnogie owrzodzenia skóry głowy i szyi
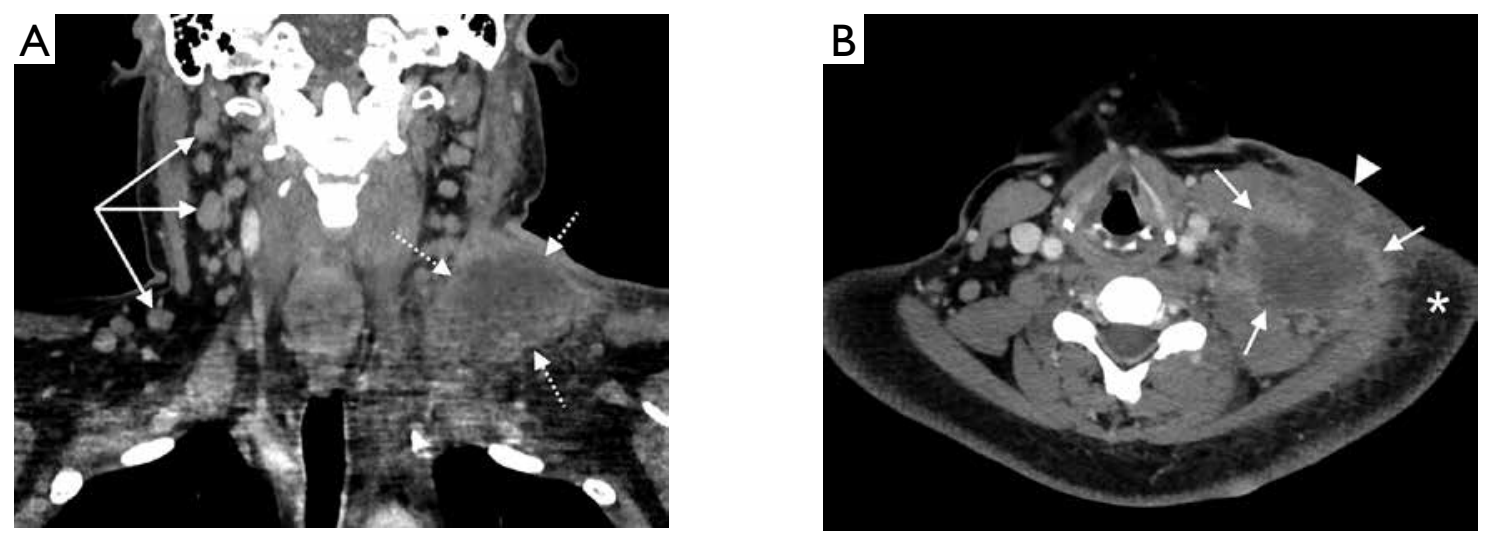

Figure 2. Contrast-enhanced computed tomography. In the coronal reconstruction (A), an abscess in the posterior cervical space is visible (dotted arrows). Additionally, lymphadenopathy on both sides of the neck is present (long arrows). In the axial plane (B) typical picture of an abscess can be appreciated (arrows) with penetration of the inflammatory process into the subcutaneous tissue (arrowhead). Oedema of the surrounding subcutaneous fatty tissue is marked by an asterisk $\left(^{*}\right)$

Rycina 2. Tomografia komputerowa po podaniu środka kontrastowego. W płaszczyźnie czołowej (A) widoczny jest ropień w tylnej przestrzeni szyi (kropkowane strzałki). Dodatkowo obecne jest powiększenie węzłów chłonnych po obu stronach szyi (długie strzałki). W płaszczyźnie osiowej (B) dostrzegalny jest typowy obraz ropnia (strzałki) z penetrującym tkankę podskórną procesem zapalnym (groty strzałek). Obrzęk otaczającej podskórnej tkanki tłuszczowej jest oznaczony gwiazdką (*)

pediculosis capitis (fig. 3). Bacterial superinfection, secondary to this infestation was the most probable cause of life-threating complications that occurred in the patient. Results of abscess's microbiological culture indicated presence of Streptococcus pyogenes and Staphylococcus aureus. Further treatment recommendations included continuation of antibiotic therapy, octenidine-based washing gel until ulceration healing and treatment of head lice by permethrin.

\section{DISCUSSION}

Pediculosis capitis may be complicated by secondary bacterial infection, usually caused by scratching of the itchy lesions on the head and neck. Bacterial complications previously reported, were mostly in the form of impetigo or bacterial cellulitis and the most common pathogens responsible - Streptococcus spp. and Staphylococcus spp. [1, 3, 5]. Mumcuoglu et al. [6] who evaluated 194 children infested with (ryc. 3). Nadkażenie bakteryjne wtórne do tej infestacji pasożytniczej było najbardziej prawdopodobną przyczyną powikłań zagrażających życiu pacjentki. Posiew mikrobiologiczny ropnia wykazał obecność Streptococcus pyogenes i Staphylococcus aureus. Dalsze zalecenia dotyczące leczenia obejmowały: stosowanie miejscowo żelu myjącego na bazie oktednidyny do czasu wygojenia się owrzodzeń, a następnie preparatu z permetryną w leczeniu infestacji pasożytniczej.

\section{OMÓWIENIE}

Wszawica głowowa może zostać powikłana wtórną infekcją bakteryjną, zwykle spowodowaną drapaniem swędzących zmian na głowie i szyi. Zgłaszane wcześniej powikłania bakteryjne miały głównie postać liszajca lub bakteryjnego zapalenia tkanki łącznej. Najczęstszymi patogenami odpowiedzialnymi za występowanie tych powikłań są Streptococcus spp. i Staphylococcus spp. $[1,3,5]$. Mumcuoglu i wsp. [6], którzy zbadali 194 dzie- 


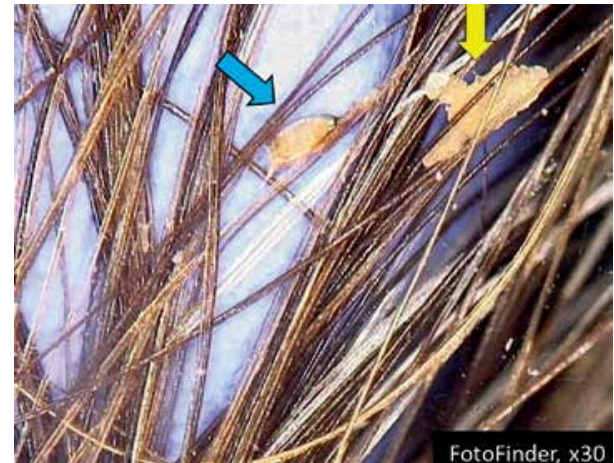

Figure 3. Trichoscopy shows vital nit (blue arrow) as well as pseudonit (yellow arrow) (non-polarized dry trichoscopy, 30× magnification, FotoFinder, Camera Medicam800 HD)

Rycina 3. W obrazie trichoskopowym widoczna jest żywa gnida (niebieska strzałka), jak również pseudognida (żółta strzałka) (trichoskopia bez immersji, światło niespolaryzowane, powiększenie 30×. FotoFinder, Camera Medicam800 HD) head lice found secondary bacterial infections in only $1 \%$.

In the described patient, alcohol addiction and poor self-hygiene contributed to the neglected form of the disease. Based on the distance between scalp skin surface and nits we estimated that infestation could start 11-12 months before.

We have not found any studies describing similar course of pediculosis capitis. Connor et al. [2] reported a patient with eczematous dermatitis caused by head lice in whom the abscesses have occurred on the lower limbs during the treatment process, probably as a result of a secondary infection associated with autoeczematization. Staphylococcus aureus was found in microbiological examination. Other serious reported complications of pediculosis capitis were anemia and sepsis $[3,7]$.

According to the study by Parhiscar and Har-El [8] the most common cause of neck abscess was dental infection, and in this study concerning 210 patients, $5.1 \%$ presented with abscess formation in the course of skin infection.

Dermoscopy (trichoscopy) is a useful, non-invasive method to assess hair and skin of the head. The characteristics of pediculosis capitis are lice and nits. Although lice are 1 to $3 \mathrm{~mm}$ long, they may move rapidly (up to $23 \mathrm{~cm} / \mathrm{min}$ ) and thus difficult to observe during trichoscopic assessment [4].

Nits are attached to the hair stem and differ in color and structures endings. Vital nits are brown and have oval ends, while empty nits are translucent grayish and have plane ends. In some cases, residues of hairspray or dandruff may mimic nits, and are called pseudonits (but these have white, amorphous structure and may be easily moved along the hair shaft) [9].

Pediculosis capitis is generally associated with a very good prognosis, however when associated with particular comorbidities or neglect it can lead to serious complications. Dermoscopy provides diagnostic clues that support the prompt diagnosis of skin infestations $[9,10]$. ci z wszawicą, stwierdzili wtórne zakażenia bakteryjne tylko u $1 \% \mathrm{z}$ nich.

U opisywanej pacjentki uzależnienie od alkoholu oraz zaniedbanie higieniczne były przyczyną wystąpienia zagrażającego życiu przebiegu choroby. Na podstawie odległości między powierzchnią skóry głowy i gnidami oszacowaliśmy, że infestacja mogła rozpocząć się 11-12 miesięcy wcześniej.

Nie znaleźliśmy prac opisujących podobny przebieg wszawicy głowowej. Connor i wsp. [2] przedstawili pacjentkę z wypryskowym zapaleniem skóry wywołanym przez wszy głowowe, u której w trakcie leczenia pojawiły się ropnie na kończynach dolnych, prawdopodobnie w wyniku wtórnej infekcji związanej z wypryskiem rozsianym. W badaniu mikrobiologicznym stwierdzono obecność gronkowca złocistego (Staphylococcus aureus). Innymi opisywanymi poważnymi powikłaniami wszawicy głowowej były niedokrwistość i posocznica [3, 7].

Według Parhiscara i Har-El [8] najczęstszą przyczyną ropnia szyi są stomatologiczne ogniska infekcji. W przeprowadzonym przez tych autorów badaniu z udziałem 210 pacjentów u 5,1\% dochodziło do powstania ropnia w przebiegu infekcji skóry.

Dermoskopia (trichoskopia) jest przydatną, nieinwazyjną metodą oceny włosów i skóry głowy. Cechą charakterystyczną wszawicy głowowej jest obecność wszy i gnid. Mimo że wszy mają długość od 1 do $3 \mathrm{~mm}$, mogą poruszać się szybko (do $23 \mathrm{~cm} / \mathrm{min}$ ), a przez to są trudne do zaobserwowania podczas badania trichoskopowego [4].

Gnidy są przyczepione do trzonu włosa i różnią się barwą i budową zakończeń. Gnidy żywotne są brązowe i mają owalne końce, natomiast puste gnidy są półprzezroczyste, szarawe i mają płaskie końce. W części przypadków pozostałości lakieru do włosów lub łupież mogą imitować gnidy i nazywane są pseudognidami (a pseudognidy mają białą, amorficzną strukturę i dają się łatwo przesuwać wzdłuż trzonu włosa) [9].

Wszawica głowowa na ogół wiąże się z bardzo dobrym rokowaniem, jednak $\mathrm{w}$ połączeniu $\mathrm{z}$ niektórymi chorobami współistniejącymi lub zaniedbana może prowadzić do poważnych powikłań. Dermoskopia 


\section{CONFLICT OF INTEREST}

The authors declare no conflict of interest. dostarcza wskazówek diagnostycznych, które wspierają szybkie rozpoznanie infestacji skórnych $[9,10]$.

\section{KONFLIKT INTERESÓW}

Autorzy nie zgłaszają konfliktu interesów.

\section{References}

\section{Piśmiennictwo}

1. Madke B., Khopkar U.: Pediculosis capitis: an update. Indian J Dermatol Venereol Leprol 2012, 78, 429-38.

2. Connor C.J., Selby J.C., Wanat K.A.: Severe pediculosis capitis: a case of "crusted lice" with autoeczematization. Dermatol Online J 2016, 22, 13030/qt7c91z913.

3. Woodruff C.M., Chang A.Y.: More than skin deep: severe iron deficiency anemia and eosinophilia associated with pediculosis capitis and corporis infestation. JAAD Case Rep 2019, 5, 444-447.

4. Nutanson I., Steen C.J., Schwartz R.A., Janniger C.K.: Pediculus humanus capitis: an update. Acta Dermatovenerol Alp Pannonica Adriat 2008, 17, 147-159.

5. Clebak K.T., Malone M.A.: Skin infections. Prim Care 2018, 45, 433-454.

6. Mumcuoglu K.Y., Klaus S., Kafka D., Teiler M., Miller J.: Clinical observations related to head lice infestation. J Am Acad Dermatol 1991, 25, 248-251.

7. Rahmadewi R., Oktaviyanti R.N.: Pediculosis capitis with complication sepsis and anemia in elderly patient: a case report. Period Dermatol Venereol 2019, 31, 165-170.

8. Parhiscar A., Har-El G.: Deep neck abscess: a retrospective review of 210 cases. Ann Otol Rhinol Laryngol 2001, 110, 1051-1054

9. Tschandl P., Argenziano G., Bakos R., Gourhant J.Y., Hofmann-Wellenhof R., Kittler H., et al.: Dermoscopy and entomology (entomodermoscopy). J Dtsch Dermatol Ges 2009, 7, 589-596.

10. Sobjanek M., Sławińska M., Bykowska B., Wilkowska A., Nowicki R.: Videodermoscopy is an effective diagnostic tool for scabies. Dermatol Rev 2016, 103, 383-386.

Received: 22.05 .2021

Accepted: 10.06 .2021

Otrzymano: 22.05.2021 r

Zaakceptowano: $10.06 .2021 \mathrm{r}$. 